\title{
EFFECT OF THERMAL FORCING OF CORMS ON THE FLOWERING OF SAFFRON (CROCUS SATIVUS L.)
}

\author{
Ibtissam MZABRI ${ }^{*}$, Maria RIMANI ${ }^{2}$, Khadija CHARIF ${ }^{1}$, Said OTOUYA $^{3}$, Noureddine KOUDDANE${ }^{1}$, \\ Abdelbasset BERRICHI ${ }^{1}$
}

\author{
${ }^{1}$ Laboratory for Agricultural Production Improvement, Biotechnology and Environment, Faculty of Science. Mohammed First \\ University, 60000, Oujda, Morocco \\ ${ }_{2}^{2}$ Laboratory of Biochemistry and Biotechnology, Faculty of Sciences. Mohammed First University, 60000, Oujda, Morocco \\ ${ }^{3}$ National Agricultural Research Institute, 60000, Oujda, Morocco
}

\begin{abstract}
Among all environmental factors, the temperature is considered one of the key elements that control the growth and development of saffron. This study was undertaken to investigate the effect of thermal forcing of corms on saffron growth and development. To this end, mother corms were collected at four different periods: late March (T2) , mid-April (T3) , late April (T4), and after leaf senescence (Control, T1) . The corms of each period were then pretreated at three successive temperature levels: at $25^{\circ} \mathrm{C}$ for 2 weeks, at $15{ }^{\circ} \mathrm{C}$ for 2 weeks and finally at $4{ }^{\circ} \mathrm{C}$ for 12 weeks. The results showed that the thermal pretreatment of corms had a significant effect on some saffron parameters. The flowers of the corms that underwent thermal treatment were later than those of the control. Similarly, the flower numbers and stigma yield were negatively affected by thermal forcing of corms. Overall, the thermal forcing of corms under the proposed regime was unfavorable for the growth and development of saffron.
\end{abstract}

Keywords: Forcing, Vegetative growth, Late flowering, Stigma yield, Daughter corms

*Corresponding author: Laboratory for Agricultural Production Improvement, Biotechnology and Environment, Faculty of Science. Mohammed First University, 60000, Oujda, Morocco

E mail: btissammzabri@gmail.com (I. MZABRI)

Ibtissam MZABRI (iD) https://orcid.org/0000-0001-9445-4131

Maria RIMANI (iD) https://orcid.org/0000-0000-1235-1452

Khadija CHARIF (iD) https://orcid.org/0000-0001-1236-1458

Said OTOUYA (iD) https://orcid.org/0000-0001-1258-1478

Noureddine KOUDDANE (iD) https://orcid.org/0000-0001-2589-1235

Abdelbasset BERRICHI (iD) https://orcid.org/0000-0001-3256-1458

Received: December 15, 2020

Accepted: January 17, 2020

Published: April 01, 2021

Cite as: Mzabri I, Rimani M, Charif K, Otouya S, Kouddane N, Berrichi A. 2021. Effect of thermal forcing of corms on the flowering of saffron (Crocus sativus L.). BSJ Agri, 4(2): 66-70.

\section{Introduction}

The saffron crocus (Crocus sativus L.; F/ Iridaceae), is a sterile geophyte with autumnal flowering, which reproduces exclusively by vegetative means (Mzabri et al., 2017). It is cultivated for its red stigmas which, after drying, are the most expensive and valuable spice in the world (Zhang et al., 2019). More recently, the demand for stigmas has increased dramatically, especially with the discovery of new pharmacological applications, especially those based on cytotoxic and antitumor properties (Cavusoglu 2017; Mzabri et al., 2019). Saffron is adapted to various environmental conditions, it grows well in arid and semi-arid areas (Gresta et al., 2008) but it can also adapt to temperate and subtropical climates. Despite these characteristics, the average productivity of saffron in Morocco remains modest with a significant annual fluctuation, of which drought during the critical stages of this species is the main cause of this fluctuation. This is in addition to traditional anthropogenic practices that have not changed since ancient times. It is also worth noting that the large burden of workforce makes the production of saffron unprofitable despite its high price on the market. Flowering saffron lasts only 2-3 weeks, and flower picking is required daily. For these reasons, research on the valorization of saffron production (Erkel 2005; Ipek et al., 2009) and the extension of harvest time (Molina et al., 2005; Erkel 2005) are gaining importance.

Some previous studies have reported that saffron production is affected by the characteristics of the growing area and the storage temperature of the corms (Turhan et al., 2010). Among all environmental factors, the role of temperature during the growth and development of saffron is very important (Ghorbani and Koocheki 2017; Agha-Hosseini et al., 2008). Similarly, spring temperatures had the greatest impact on saffron yield. In general, saffron does not need cold to lift dormancy of corms as in other geophytes (Dole 2003). On the other hand, flowering requires a warmintermediate temperature regime (Molina et al., 2005). High temperatures $\left(23-27^{\circ} \mathrm{C}\right)$ are required to break bud dormancy and for flower initiation, which takes place from early spring to mid-summer, depending on location (Greenberg-Kaslasi 1991; Molina et al., 2005). 


\section{Black Sea Journal of Agriculture}

Previous research has tested the thermal pretreatment effect of corms on saffron production (Gómez et al., 2002). The same authors stated that storing bulbs at 30 ${ }^{\circ} \mathrm{C}$ for 45 days increased the number of flowers compared to bulbs forced to germinate directly at $17 / 10{ }^{\circ} \mathrm{C}$ after leaf wilting. In this work, this is part of a series of experiments that aim at the agronomic valorization of saffron in the semi-arid region of Eastern Morocco. The effect of pre-treatment of corms with a new thermal regime on the harvest period, stigma yield and reproduction of corms was evaluated in the open field.

\section{Material and Methods}

This study was conducted at the Faculty of Science of Oujda during the year 2018-2019. The climatic data of the site showed that rainfall, average monthly temperature were respectively $226 \mathrm{~mm}, 18{ }^{\circ} \mathrm{C}$ respectively. The corms used in this trial were taken from the breeding squares within the experimental research station of the Faculty of Science of Oujda planted on 21/09/2015.

To study the effect of heat pre-treatment of the corms on the floral initiation of saffron, the corms were carefully unearthed at four different periods: late March (T2), midApril (T3), late April (T4), and after leaf senescence (control, T1). The corms from each period were then placed in black plastic bags containing the same culture substrate before being incubated at 3 successive temperatures: $25^{\circ} \mathrm{C}$ for 2 weeks, $15^{\circ} \mathrm{C}$ for 2 weeks and 4 ${ }^{\circ} \mathrm{C}$ for 12 weeks. The control group, collected after leaf senescence (mid-May, T1), was kept in the dark at room temperature until planting.

When filling the pots, the substrate composed of a mixture of peat and sand (2/3 and $1 / 3 \mathrm{v} / \mathrm{v}$ respectively) was prepared, and then the well-decomposed sheep manure was incorporated at a rate of $180 \mathrm{~g} /$ pot $(30 * 35$ $\mathrm{cm}$ ) equivalent to the dose recommended for saffron cultivation, i.e. 20-30T / ha. On August 28, 2018, the corms that underwent the different treatments were planted, with a distance of $5 \mathrm{~cm}$ between the corms (in all directions) and at a depth of $7 \mathrm{~cm}$.

The first irrigation was carried out at the end of September, and then due to the favorable and sufficient rainfall during the month of October, no irrigation was carried out. Subsequently, the plants were irrigated with a quantity of water equivalent to $100 \%$ ET0 (reference evapotranspiration) from the city of Oujda.

When the flowers were opened, the stigmas were manually separated and dried in the shade to constant weight to determine the spice yield (mg). Then the first and last dates of flowering were noted in order to determine the total harvest period in the number of days of flowering. Then at the end of the growing cycle, the daughter corms were counted (corms/plant), weighed using a scale (g), and calibrated using a caliper (cm/daughter corm).

The trial was conducted under a complete randomized block design with 4 treatments and 9 replicates, totaling 36 pots, each containing five saffron plants for a total of 180 plants. The treatments studied were: T1: control (no pre-treatment), T2: corms collected at the end of March, T3: corms collected mid-April, and T4: corms collected at the end of April. The significance of the differences was tested by the ANOVA. Where appropriate, mean separation was performed using the Duncan test at the $5 \%$ significance level.

\section{Results}

\subsection{Flowering Period}

Field observations show that thermal forcing of the corms has a very remarkable effect on the flowering date of saffron. The control corms flowered during the usual flowering period of this species under the climatic conditions of the eastern region of Morocco, namely between October and November. However, the flowers of the corms that underwent a heat treatment flowered late, the first flowers were observed on December 20, 25 and 27 respectively for the treatments $\mathrm{T} 2, \mathrm{~T} 3$ and $\mathrm{T} 4$, the flowering period spread until January (Table 1 ).

Table1. The forcing effect of saffron corms on flowering dates

\begin{tabular}{|c|c|c|c|c|c|}
\hline \multirow[t]{2}{*}{ Treatment } & \multicolumn{5}{|c|}{ Treatment Date of the first- last bloom } \\
\hline & October & November & December & January & February \\
\hline \multicolumn{6}{|l|}{ Control } \\
\hline \multicolumn{6}{|l|}{$\mathrm{T} 2(\mathrm{FM})$} \\
\hline \multicolumn{6}{|l|}{ T3 (MA) } \\
\hline $\mathrm{T} 4(\mathrm{FA})$ & & & & & \\
\hline
\end{tabular}

\subsection{Performance Parameters}

Yield is considered to be the result of the coordination of several components such as the number of flowers and the weight of stigmas. The results of the performance components are shown in Figure 2B, show that flower number and stigma yield were negatively affected by thermal forcing of corms. Comparison of means showed that the control had the highest number of flowers and therefore the highest stigma yield with respective averages of 0.85 flower / corm and $68.5 \mathrm{mg} / 380 \mathrm{~cm}^{2}$. 


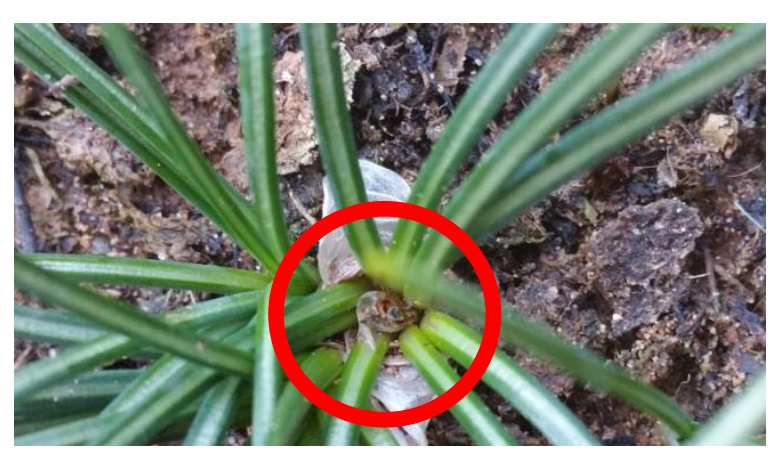

Figure 1. Aborted saffron flower observed in the T4 treatment.

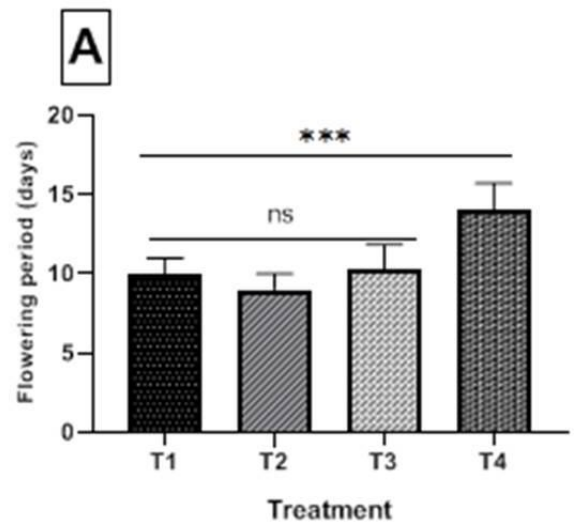

B

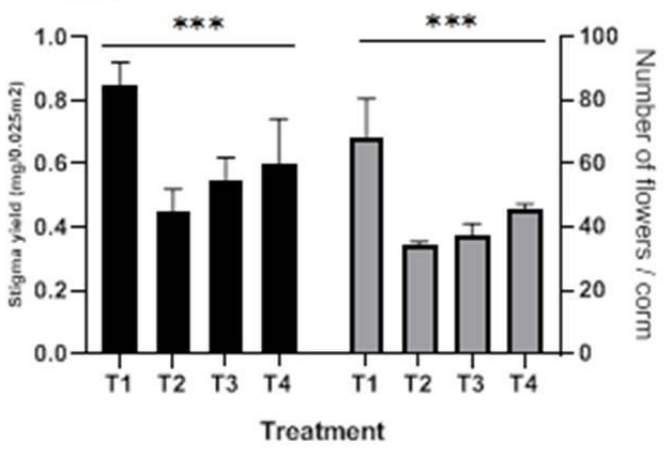

Number of flowers $\square$ Stigma yield
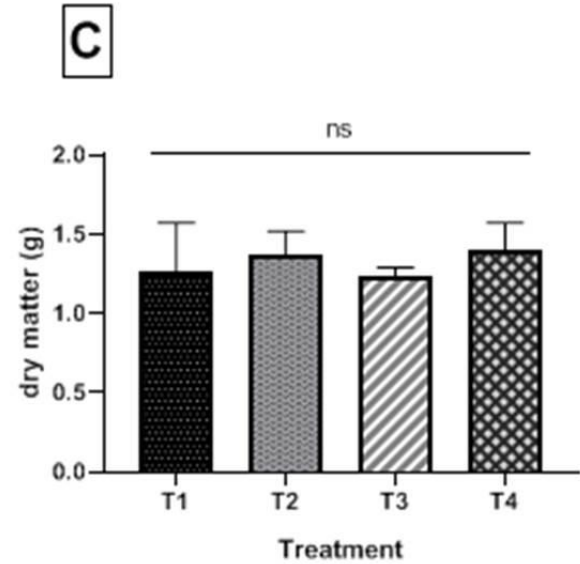

Figure 2. Effect of thermal forcing of saffron corms on the flowering period $(\mathrm{A})$, number of flowers and weight of stigmas (B) and aerial dry matter (C). The values are the averages of 9 replicates. ${ }^{* * *}=\mathrm{P} \leq 0.001$.
While T2 and T3 treatments showed the lowest values of these measured parameters. Similarly, the results showed that the T4 treatment (corms collected at the end of April) showed the abortion of some flowers (Figure 1) and a longer harvest period, i.e. 14 days compared to other treatments which recorded an average period of 9 days. These results were confirmed by analysis of variance which revealed a highly significant difference between $\mathrm{T} 4$ treatment and other treatments in terms of precocity and harvest duration $(\mathrm{P}=0.015)$. At the end of the crop cycle, before the total wilting of the leaves, the aerial dry matter of each treatment was measured.

The highest values were recorded for the corms collected at the end of April (T4) with $1.4 \mathrm{~g} / \mathrm{pot}$, an increase of $14 \%$ compared to the control. However, this observed difference was not statistically significant between different treatments (Figure 2C).

\subsection{Parameters of the Underground Part}

According to the results of the parameters of the underground part, the number, weight and diameter (Figure 3) of daughter corms were also affected by the different treatments applied.

\section{A}

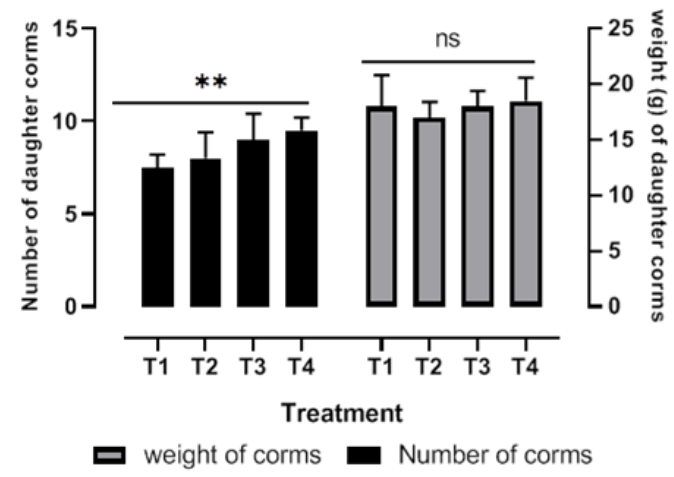

B

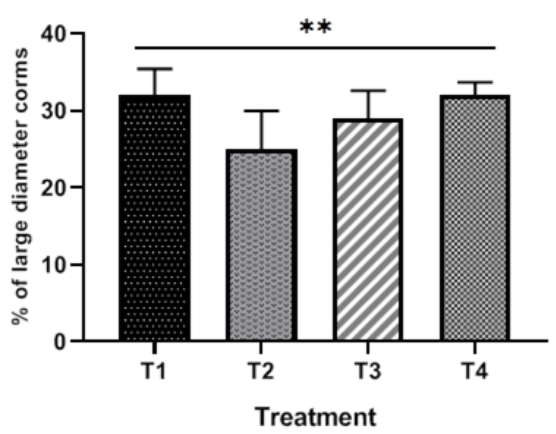

Figure 3. Thermal forcing effects of the rudder horns on the parameters of the underground part. A. number and weight (g) of daughter corms; B. large daughter corms $(\%)$. The data are the average of 9 repetitions. ${ }^{* *}=\mathrm{P} \leq$ 0.05 .

Thermal forcing induced an increase in the number of daughter corms produced regardless of the sampling period of the mother corms. In addition, the highest 


\section{Black Sea Journal of Agriculture}

number of corms was obtained in the case of T3 and T4, with respective values of 8 and 9 corms per plant. While, despite this increase which was highly significant $(p=0.01)$, the total weight of corms did not show a significant difference between treatments $(p>0.05)$. The results also show that the percentage of large diameter corms varies according to the treatment applied. The control scored the highest percentage with a value that exceeded $30 \%$. While the corms that underwent thermal forcing showed lower values than the control, a reduction of $22 \%$ was recorded in the T2 treatment (corms collected at the end of March).

\section{Discussion}

Saffron is an autumnal flowering plant whose production is affected by several environmental and anthropogenic factors. Several previous studies (Molina et al., 2005; Dror 1983; Plessner et al., 1990) have been used to define several methods to control flowering and vegetative reproduction of saffron Crocus. Corm storage temperature is one of the factors influencing saffron production (De Mastro and Ruta 1993; Molina et al., 2004). In this study, saffron corms were collected at four different periods: late March (T2), mid-April (T3), late April (T4), and after leaf senescence (control, T1). The corms from each period were then pre-treated at three temperature levels $25^{\circ} \mathrm{C}$ for 2 weeks, $15^{\circ} \mathrm{C}$ for 2 weeks, and $4{ }^{\circ} \mathrm{C}$ for 12 weeks. According to the data, the thermal pre-treatment of the corms had a significant effect on certain parameters of the saffron. The results showed that thermal forcing at different temperatures induced late flowering with a delay of almost two months compared to the control. These results are in agreement with those of (Molina et al., 2004) where the increase in cold storage duration induced a further extension of the flowering period but with a significant loss of saffron yield.

It should be noted that despite the loss of yield, this new extension of the flowering period could be economically interesting. However, our results disagree with other spring-flowering bulbous species such as Crocus flavus (Wilkins 1985), Muscari, Iris (Gómez et al., 2002) which require a sequence of warm-cold-warm temperatures to flower (Wilkins 1985). C. sativus flowers best in a warmintermediate temperature sequence (Molina et al., 2004). Indeed, the direct storage at a low temperature of the corms acts on the precocity and extension of the saffron flowering season (Molina et al., 2005; Cavusoglu 2010; Mzabri et al., 2017; Hajyzadeh et al., 2017) which invalidates the results found in this trial. In addition, the results showed that flower number and stigma yield were negatively affected by the thermal forcing of the corms. This has been confirmed by most of the experiments that have studied the effect of corm forcing on the growth of saffron, where storage at low temperature led to a reduction in the number of flowers formed in saffron and thus a reduction in stigmas. Similarly, (Molina et al., 2004) found that the transfer of bulbs after floral initiation at a temperature below $15{ }^{\circ} \mathrm{C}$, caused a drastic reduction in the number of flowers formed. While (Hajyzadeh et al., 2017) proved that corms stored in cold storage showed a better yield of saffron and had positive effects on all components of the plant. The reduction of yield parameters (number and size of flowers) due to low-temperature storage was closely dependent on the stage of development of the mother corms, storage conditions, and duration (Molina et al., 2005). This is in perfect agreement with the results of the present research where corm forcing affected yield parameters differ depending on the stage of mother corm removal, where corm removal at the end of March resulted in flower abortion. While (Amooaehaie 2007) elucidated that saffron corms removed after leaf wilting and stored at $2{ }^{\circ} \mathrm{C}$ for 60 days could be forced to flower from early November to late December with the same spicy saffron yield as non-cold stored corms. The forcing also influenced the parameters of the daughter corms, it induced an increase in the daughter corm produced but of small diameter. Similar results were found by (Çavuşoğlu 2010; Mzabri et al., 2017) who reported the negative effects of cold storage on the weight and diameter of daughter corms in saffron.

\section{Conclusion}

The results of the present study highlighted the effect of forcing saffron corms with a new thermal regime on the agronomic parameters of the crop. This experiment aimed to stagger the saffron harvesting period in order to minimize the high demand for the workforce. The results showed that the thermal forcing of the corms whatever the harvesting period induced a late flowering coupled with a significant decrease in the yield of the spice. The effect on the subterranean part resulted in an increase in the number of daughter corms with a small diameter $<<$ $1.5 \mathrm{~cm}$ ). Nevertheless, a high number of corms, whatever their size, can be exploited as propagation material by nurserymen.

\section{Author Contributions}

IM; conceptualization and wrote the manuscript, MR and $\mathrm{KCH}$; writing original draft preparation, So; review and editing, $\mathrm{NK}$ and $\mathrm{AB}$; supervision.

\section{Conflict of Interest}

The authors declare that there is no conflict of interest.

\section{References}

Agha-Hosseini M, Kashani L, Aleyaseen A, Ghoreishi A, Rahmanpour H, Zarrinara A R, Akhondzadeh S. 2008. Crocus sativus L. (saffron) in the treatment of premenstrual syndrome: A double-blind, randomised and placebocontrolled trial. BJOG-Int J Obstet Gy, 115(4): 515-519.

Amooaehaie R. 2007. Low temperature storage of corms extends the flowering season of saffron (Crocus sativus L.). Acta Hortic, 739: 41-47.

Çavuşoğlu A. 2010. The effects of cold storage of saffron (Crocus 


\section{Black Sea Journal of Agriculture}

sativus L.) corms on morphology, stigma and corm yield. Afr ] Agric Res, 5(14): 1812-1820.

Cavusoglu A. 2017. The Effect of Exogenously Applied Plant Growth Regulators on Plant Development of Saffron (Crocus sativus L.). J Inst Sci Technol, 7(1): 17-22.

De Mastro G, Ruta C. 1993. Relation between corm size and saffron (Crocus sativus L.) flowering. Acta Hortic, 344(58): 512-517.

Dole J. 2003. Research Approaches for Determining Cold Requirements for Forcing and Flowering of Geophytes. Hort Sci, 38(3): 341-346.

Dror A. 1983. The control of flowering and vegetative reproduction of the saffron Crocus (Crocus sativus). M.Sc thesis, Faculty of Agriculture, Hebrew University of Jerusalem.

Erkel E İ. 2005. Kocaeli ili koşullarinda safran (Crocus sativus l.) yetiștiriciliğinde yetişme yeri ve korm çapi'nin verim ve erkencilik üzerine etkisi. Akdeniz Univ Ziraat Fak Derg, 18(2): 179-184.

Ghorbani R, Koocheki A. 2017. Sustainable Cultivation of Saffron in Iran. J Sustain Agr, 25: 169-203.

Greenberg-Kaslasi D. 1991. Vegetative and reproductive development in the saffron Crocus (Crocus sativus L.). MSc. Thesis, The Hebrew University of Jerusalem, Isreal.

Gresta F, Lombardo G M, Siracusa L, Ruberto G. 2008. Saffron, an alternative crop for sustainable agricultural systems. A review. Agron Sustain Dev, 28(1): 95-112.

Hajyzadeh M, Asil H, Yildirim M U, Sarihan E O, Ayanoglu F, Khawar K M. 2017. Evaluating effects of corm circumferenc and storage temperatures on yield and yield components of saffron at different elevations. Acta Hortic, 1184(6): 39-46

Ipek A, Arslan N, Sarihan E O. 2009. Effects of different planting depth and bulb sizes on yield and yield components of saffron (Crocus sativus L.). Ankara Üniv, Ziraat Fak, Tarım Bilim Derg, 15(1): 38-46.

Molina R V, Valero M, Navarro Y, García-Luis A, Guardiola J L.
2004. The effect of time of corm lifting and duration of incubation at inductive temperature on flowering in the saffron plant (Crocus sativus L.). Sci Hort, 103(1): 79-91.

Molina R V, Valero M, Navarro Y, García-Luis A, Guardiola J L. 2005. Low temperature storage of corms extends the flowering season of saffron (Crocus sativus L.). J Hortic Sci Biotechnol, 80(3): 319-326.

Molina R, Valero M, Navarro Y, Guardiola J, García-Luís A. 2005. Temperature effects on flower formation in saffron (Crocus sativus L.). Sci Hort, 103(3): 361-379.

Muñoz Gómez R M, de Juan Valero J A, Botella Miralles O, Moya Aparicio A. 2002. Efectos del mantenimiento a elevadas vegetativa y la producción de flores y cormos huos en el azafrán (Crocus sativus L .). Int Technol Ed Assoc, 98(3): 200212.

Mzabri I, Addi M, Berrichi A. 2019. Traditional and modern uses of saffron (Crocus sativus). Cosmetics, 6(4): 1-11.

Mzabri I, Legsayer M, Chetouani M, Aamar A, Kouddane N, Boukroute A, Bekkouch I, Berrichi A. 2017. Saffron (Crocus sativus L.) yield parameter assessment of abiotic stressed corms stored in low temperature. J Mater Environ Sci, 8(10): 3588-3597.

Plessner 0, Ziv M, Negbi M. 1990. In vitro corm production in the saffron crocus (Crocus sativus L.). Plant Cell, Tissue and Organ Cult, 20(2): 89-94.

Turhan H, Kahriman F, Egesel C O, Gul M K. 2010. The effects of different growing media on flowering and corm formation of saffron (Crocus sativus L.). Afr J Biotechnol, 20(6): 2328-2332.

Wilkins H F. 1985. Crocus vernus: Crocus sativus. In Halevy, AH. Handbook of flowering. CRC Press, Vol. 2, Boca Raton, FL, 350355.

Zhang A, Shen Y, Cen M, Hong X, Shao Q, Chen Y, Zheng B. 2019. Polysaccharide and crocin contents, and antioxidant activity of saffron from different origins. Ind Crops Prod, 133: 111 117. 